\author{
ROBERT DULIŃSKI, ŁUKASZ BYCZYŃSKI, ADRIAN KARBOWSKI
}

\title{
OKREŚLENIE ZAWARTOŚCI WYBRANYCH KWASÓW FENOLOWYCH I WITAMIN Z GRUPY B W PIECZYWIE ŻYTNIM WZBOGACONYM W ALGI ORAZ OSZACOWANIE BIODOSTĘPNOŚCI TYCH ZWIĄZKÓW IN VITRO
}

\author{
Streszczenie
}

W ostatnich latach obserwuje się rosnące zainteresowanie wzbogacaniem żywności ekstraktami bądź innymi składnikami pochodzącymi z biomasy alg. Skład i właściwości zarówno mikroalg, jak i makroalg (wodorostów) predestynują je do tego, aby nie tylko stanowiły uzupełnienie niedoborów wybranych składników biologicznie czynnych w diecie, ale pełniły również rolę czynników decydujących o prozdrowotnym charakterze produktu.

$\mathrm{W}$ pracy podjęto próbę zaprojektowania pieczywa funkcjonalnego zawierającego biomasę $\mathrm{z}$ alg Arthrospira platensis i Ascophyllum nodosum. Analizie poddano wybrane składniki bioaktywne alg oraz oszacowano ich biodostępność techniką in vitro. Z oznaczeń HPLC, a następnie symulacji trawienia w przewodzie pokarmowym człowieka wynika, że wzbogacenie pieczywa żytniego algami wpływa na 2-, 3-krotny wzrost zawartości witaminy $\mathrm{B}_{2}$, co w przypadku jednego $\mathrm{z}$ wariantów chleba zapewnia zrealizowanie blisko $30 \%$ zalecanej dziennej dawki ryboflawiny oraz wzrost o $50 \div 145 \%$ zawartości tiaminy w stosunku do zawartości tej witaminy w pieczywie pozbawionym dodatków algowych przy porównywalnym z próbą kontrolną poziomie biodostępności in vitro (60\%). W projektowanym pieczywie odnotowano również istotny wzrost zawartości wybranych kwasów fenolowych, głównie galusowego oraz wanilinowego przy zróżnicowanym poziomie biodostępności in vitro sumy polifenoli w zakresie $17 \div$ $30 \%$. Wyniki przedstawionych analiz oraz pozytywne (niepublikowane) noty testów sensorycznych stwarzają obiecującą perspektywę dla wprowadzenia funkcjonalnego pieczywa z dodatkiem alg na rynek produktów piekarniczych.

Słowa kluczowe: mikroalgi, Arthrospira platensis, kwasy fenolowe, ryboflawina, tiamina, biodostępność

\section{Wprowadzenie}

Przetworzone ziarno zbóż tradycyjnie jest jednym z podstawowych produktów spożywczych, jednak w ostatnich latach konsumpcja, zwłaszcza pieczywa, zmniejszyła

Dr hab. R. Duliński, dr E. Byczyński, Katedra Biotechnologii Żywności, Wydz. Technologii Żywności, Uniwersytet Rolniczy w Krakowie, ul. Balicka 122, 31-149 Kraków, mgr inż. A. Karbowski, Algitect, ul.Łódzka 22/27, 98-220ZduńskaWola.Kontakt:r.dulinski@ur.krakow.pl 
się z uwagi na zmianę stylu życia. Stąd potrzeba rozwoju nowych wersji produktów piekarskich, które sprostałyby oczekiwaniom konsumentów zwracających uwagę na wartość odżywczą kupowanych artykułów żywnościowych. Wzbogacone produkty zbożowe mogą dostarczyć dodatkowych składników odżywczych, jak również składników mineralnych i witamin, wpisując się w definicję żywności funkcjonalnej.

Ze względu na swój skład chemiczny algi znajdują zastosowanie jako składnik pasz i żywności podwyższający ich wartość odżywczą [2]. Obecnie algi odgrywają kluczową rolę jako składnik pasz w chowie zwierząt w akwakulturach (ryb, skorupiaków, małży) $[11,18]$. Do substancji o potencjale bioaktywnym, występujących w znaczących ilościach w mikroalgach, można zaliczyć m.in. karotenoidy, kwasy tłuszczowe, witaminy a także mikroelementy i wysoko wartościowe białko [2, 3, 14]. Cyjanobakterie z rodzaju Spirulina uznawane są za potencjalny dodatek do żywności m.in. ze względu na dużą zawartość białka $(65 \div 70 \%$ s.m.), witamin (głównie $\beta$-karotenu) oraz składników mineralnych $[6,28,30]$. Wysoki poziom protein w komórkach Arthrospira platensis związany jest przede wszystkim z obecnością fikocyjaniny, przeciwutleniacza, który stosowany jest jako składnik różnego rodzaju produktów przemysłu kosmetycznego i farmaceutycznego [13, 16]. Prowadzone są także badania, których celem jest ekstrakcja i wykorzystanie peptydów pochodzących również z innych gatunków alg, m.in. Chlorella, które mogą działać jako inhibitory enzymu konwertującego angiotensynę ACE [17] lub pełnić inne funkcje terapeutyczne [7, 30].

W produkcji żywności podejmowano już próby dodawania glonów morskich do pieczywa [4, 8], jak również ekstraktów z Arthrospira platensis czy Chlorella do ciastek [19] - w tym ostatnim przypadku zakończone wprowadzaniem produktu do obrotu na hiszpańskim rynku wyrobów piekarskich [32].

Celem niniejszej pracy było zaprojektowanie funkcjonalnego pieczywa wzbogaconego w ekstrakty z alg (Ascophyllum nodosum, Arthrospira platensis) oraz analiza zawartości jego wybranych składników bioaktywnych: kwasów fenolowych oraz witamin $\mathrm{B}_{1} \mathrm{i} \mathrm{B}_{2}$. W ramach przedstawionych badań podjęto również próbę oszacowania przyswajalnej puli tych związków poprzez zastosowanie procedury in vitro symulującej trawienie w przewodzie pokarmowym człowieka.

\section{Material i metody badań}

\section{Algi}

Biomasę mikroalgi Arthrospira platensis zakupiono w Ecoduna GmbH (Austria), natomiast makroalgi morskiej Ascophyllum nodosum w Seaweed \& Co Ltd. (Wielka Brytania). Sól algową zakupiono w Setalg (Francja). Sól algowa otrzymywana jest 
z ekstraktów makroalg (wodorostów morskich) i zawiera 8 - $\div$ 10-krotnie mniej sodu niż sól kuchenna.

\section{Przygotowanie ciasta}

Pieczywo żytnie zostało przygotowane w lokalnej piekarni („Prawdziwy Chleb” P.P.H.U. Agnieszka Gajda-Sokołowska, Polska), zgodnie z poniższą procedurą.

Ciasta na pieczywo przygotowano z następujących składników: mąka żytnia typu 2000, zakwas żytni, woda i sól oraz odpowiednie składniki mikroalgowe wymienione w tab. 1. Po ręcznym wymieszaniu ciasta formowano kęsy o masie $1,15 \mathrm{~kg}$, umieszczano je w metalowych formach i pozostawiano do fermentacji na $3 \mathrm{~h} w$ komorze rozrostu o stałej wilgotności i temp. $35,5^{\circ} \mathrm{C}$, a następnie przenoszono do komory wypiekowej. Wypiek prowadzono w piecu o temp. $250{ }^{\circ} \mathrm{C}$ przez $30 \mathrm{~min}$. Pieczywo po wyjęciu z pieca pozostawiano na $2 \mathrm{~h}$ do schłodzenia.

\section{Metoda in vitro}

Biodostępność polifenoli oraz witamin szacowano przy zastosowaniu metody in vitro opracowanej przez Żyłę i wsp. [31] do badania drobiu, a następnie zmodyfikowanej przez Starzyńską-Janiszewską i wsp. [25] pod względem symulacji warunków panujących w żołądku i jelicie cienkim człowieka. Pół grama próbki inkubowano z 1,7 mg pepsyny (Sigma-Aldrich, Steinheim, Niemcy; deklarowana aktywność $4750 \mathrm{U} / \mathrm{mg}$ ) rozpuszczonej w roztworze $0,1 \mathrm{~mol} / 1 \mathrm{HCI}$, w temp. $37^{\circ} \mathrm{C}, \mathrm{pH}=2,0 \mathrm{przez}$ 2 h. Następnie wprowadzano 2,5 mg pankreatyny (Sigma-Aldrich, Steinheim, Niemcy; $\mathrm{z}$ trzustki świni, $8 \times$, United States Pharmacopeia) rozpuszczonej w roztworze $0,1 \mathrm{~mol} / \mathrm{l}$ $\mathrm{NaHCO}_{3}$, a całość próbki przenoszono do woreczków dializacyjnych (Sigma-Aldrich, Steinheim, Niemcy; błona celulozowa, $25 \mathrm{~mm} \times 90 \mathrm{~mm}$, MWCO 12000), zamykano klipsami i inkubowano przez $4 \mathrm{~h} \mathrm{w}$ temp. $37^{\circ} \mathrm{C}$ w kolbkach zawierających po $50 \mathrm{ml}$ buforu imidazolowego o $\mathrm{pH}=7,0$. Uzyskane dializaty wykorzystano do analiz HPLC.

Termin „biodostępność in vitro” zdefiniowano jako współczynnik pomiędzy zawartością związków w dializacie (w tym przypadku polifenoli lub witamin, które przekroczyły barierę porów w błonie dializacyjnej i znalazły się w roztworze buforu $\mathrm{w}$ trakcie symulowanego trawienia in vitro) wobec całkowitej ich zawartości w materiale wyjściowym wyrażony w $\%(\mathrm{~m} / \mathrm{m})$. 


\begin{tabular}{|c|c|c|c|c|c|c|}
\hline 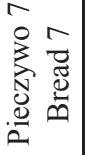 & 0 & 0 & 0 & & 0 & 0 \\
\hline 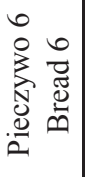 & 0 & 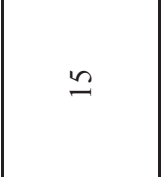 & $\stackrel{2}{1}$ & 으 & 0 & $\circ$ \\
\hline 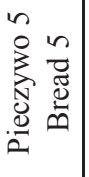 & ¿ & 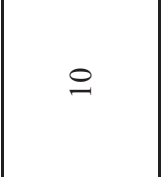 & $\stackrel{0}{1}$ & 0 & 10 & q \\
\hline 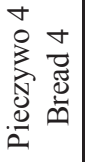 & 0 & 은 & तิ & 인 & 0 & in \\
\hline 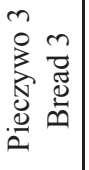 & $\stackrel{?}{2}$ & 0 & 0 & 0 & a & in \\
\hline 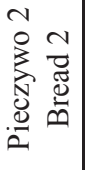 & in & in & 0 & 0 & 으 & in \\
\hline 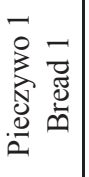 & 0 & 0 & 0 & 0 & $\stackrel{\infty}{-\infty}$ & 0 \\
\hline 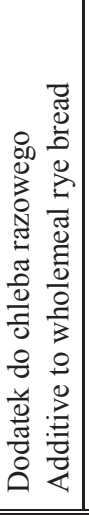 & 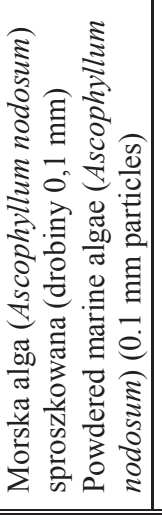 & 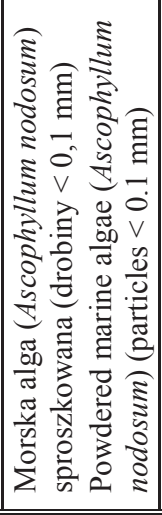 & 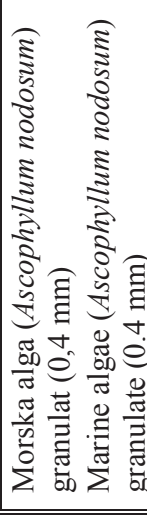 & 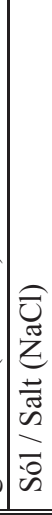 & 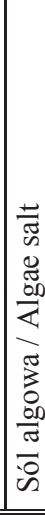 & 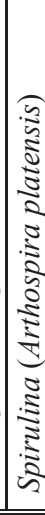 \\
\hline
\end{tabular}




\section{Oznaczanie polifenoli}

\section{Ekstrakcja}

Do analiz chromatograficznych ekstrakty sporządzano poprzez zalanie $0,5 \mathrm{~g}$ próbki $10 \mathrm{ml}$ mieszaniny ekstrakcyjnej o składzie woda/metanol/kwas octowy $(69 / 30 / 1)$ i umieszczenie w łaźni wodnej $\left(50{ }^{\circ} \mathrm{C}\right) \mathrm{z}$ wytrząsaniem przez $60 \mathrm{~min}$. Tak przygotowane próbki filtrowano przez filtr papierowy KA4, a następnie przez nylonowe filtry strzykawkowe $0,22 \mu \mathrm{m}$ (Phenomenex, Torrance, CA, USA) do fiolek z ciemnego szkła i przechowywano w chłodziarce $\left(4^{\circ} \mathrm{C}\right)$ do czasu wykonywania oznaczeń.

\section{Metoda HPLC (High Performance Liquid Chromatography)}

Oznaczanie poszczególnych związków fenolowych prowadzono metodą, którą opisali Rodríguez-Bernaldo i wsp. [21] oraz Machu i wsp. [12]. Analizy wykonywano z użyciem wysokosprawnego systemu chromatograficznego UltiMate 3000 (Dionex, California, USA) z detektorem DAD. W celu rozdzielenia poszczególnych związków fenolowych zastosowano kolumnę typu C18 Kinetex (wymiary: $150 \mathrm{~mm} \times 4,6 \mathrm{~mm}$, średnica ziaren 2,6 $\mu \mathrm{m}$ - Phenomenex, Torrance, CA, USA) i detekcję spektrofotometryczną przy długości fali $\lambda=275 \mathrm{~nm}$. Kolumnę termostatowano w temp. $23{ }^{\circ} \mathrm{C}$, prędkość przepływu eluentu wynosiła $1 \mathrm{ml} / \mathrm{min}$, a objętość nastrzyku próbki - $10 \mu \mathrm{l}$. Rozdział prowadzono z wykorzystaniem dwuskładnikowego gradientu, w którym fazę A stanowiła mieszanina woda : kwas octowy $(99: 1)$, a fazę B mieszanina woda : acetonitryl : kwas octowy $(67: 32: 1)$.

\section{Oznaczanie witamin $B_{1}$ oraz $B_{2}$}

Oznaczanie witamin $\mathrm{B}_{1}$ i $\mathrm{B}_{2}$ wykonywano zgodnie $\mathrm{z}$ opisem podanym przez Starzyńską-Janiszewską i wsp. [24]. Rozdział ryboflawiny $\left(\mathrm{B}_{2}\right)$ i tiaminy $\left(\mathrm{B}_{1}\right)$, jako thiochromu, prowadzono techniką wysokosprawnej chromatografii cieczowej w odwróconej fazie w kolumnie Luna C18, (wymiary: $250 \mathrm{~mm} \times 4 \mathrm{~mm}$, średnica ziaren $5 \mu \mathrm{m}-$ Phenomenex, Torrance, CA, USA) izokratycznie $\mathrm{z}$ wykorzystaniem fazy ruchomej składającej się z mieszaniny metanolu i $0,05 \mathrm{M}$ octanu sodu $(30: 70 \mathrm{v} / \mathrm{v})$ przy prędko-

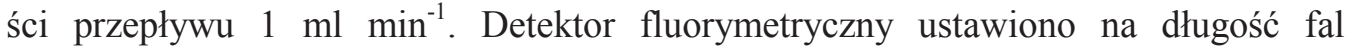
wzbudzenia $\lambda=366 \mathrm{~nm}$ i emisji $\lambda=435 \mathrm{~nm}$ w przypadku witaminy $\mathrm{B}_{1}$ oraz $\lambda=$ $422 \mathrm{~nm} / 533 \mathrm{~nm}$ w przypadku oznaczania witaminy $\mathrm{B}_{2}$. Konwersję tiaminy do tiochro$\mathrm{mu}$ prowadzono zakolumnowo z wykorzystaniem odczynników utleniających $(0,1$ procentowy żelazicyjanek potasu w 12-procentowym wodorotlenku sodu) podawanych przez pompę perystaltyczną (Dionex ISO-3000) z przepływem $0,2 \mathrm{ml} / \mathrm{min}$ z wykorzystaniem uformowanej pętli reakcyjnej z teflonu o pojemności $750 \mu 1$ (VICI-Valco, Houston, USA). 
Analiza statystyczna

Wyniki badań poddano jednoczynnikowej analizie wariancji (ANOVA) w celu oszacowania istotności różnic między wartościami średnimi. Różnice między wartościami średnimi weryfikowano testem Tukeya przy $\mathrm{p} \leq 0,05$ za pomocą oprogramowania Statistica ver. 12.5 (Statsoft Inc., Tulsa, OK, USA).

\section{Wyniki i dyskusja}

Określenie profilu polifenoli

Kwasy fenolowe to istotna grupa substancji organicznych pochodzenia roślinnego, do której należą związki zawierające pierścień fenolowy i resztę kwasu karboksylowego. Pełnią one funkcje antyoksydacyjne oraz wpływają korzystnie na parametry sensoryczne żywności $[9,20]$, W trakcie trawienia w przewodzie pokarmowym występują w zróżnicowanej formie i w różnym stopniu są wchłaniane z jelit.

Analizy HPLC ekstraktów próbek pieczywa pozwoliły wykazać statystycznie istotny wpływ wzbogacenia algami na poziom kwasu galusowego. Odnotowano 2-, 3krotny wzrost zawartości tego związku wobec próbki kontrolnej $(15,08 \mu \mathrm{g} / \mathrm{g})$ (pieczywo 7) do poziomu 53,60 $\mu \mathrm{g} / \mathrm{g}$ w przypadku próbki pieczywa 3 wzbogaconej maksymalną dawką Arthrospira platensis (50 g/kg mąki) oraz dodatkowo Ascophyllum nodosum (10 g/kg mąki) - tab. 2. Podobne tendencje zaobserwowano w przypadku kwasu wanilinowego, gdzie najwyższy poziom tego bioaktywnego składnika oznaczono również w pieczywie 3, a statystycznie istotny wzrost jego zawartości wobec próby kontrolnej odnotowano w 5 próbkach pieczywa spośród 6 wzbogaconych algami.

Kwasy fenolowe wraz z flawonoidami, lignanami i stilbenami stanowią grupę związków o właściwościach antyoksydacyjnych, określanych jako polifenole. Sumę tych związków oznaczono w ekstraktach z próbek chleba oraz w dializatach otrzymanych w wyniku symulacji trawienia $\mathrm{w}$ przewodzie pokarmowym techniką in vitro. Otrzymane wyniki wskazują na zróżnicowany poziom biodostępności in vitro polifenoli (od 17 do $30 \%$ ) w analizowanych próbkach (tab. 2).

W ujęciu procentowym biodostępność szacowana in vitro była mniejsza w przypadku próbek pieczywa wzbogaconych w algi, zwłaszcza w Arthrospira platensis (pieczywo 2 - 4), w stosunku do pieczywa kontrolnego. Po wyrażeniu tych wartości w jednostkach bezwzględnych próbki pieczywa wciąż dostarczały największą pulę przyswajalnych polifenoli. 
Tabela 2. Zawartość wybranych kwasów fenolowych oraz biodostępność in vitro sumy polifenoli w pieczywie wzbogaconym w algi

Table 2. Contents of selected phenolic acids and in vitro bioavailability of polyphenols in total in breadstuffs enriched with algae

\begin{tabular}{|c|c|c|c|c|c|}
\hline $\begin{array}{c}\text { Nazwa } \\
\text { próbki } \\
\text { Name of } \\
\text { sample }\end{array}$ & 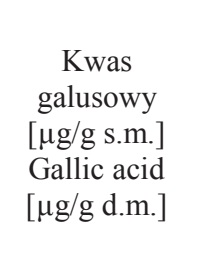 & 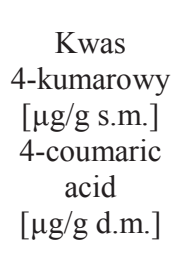 & 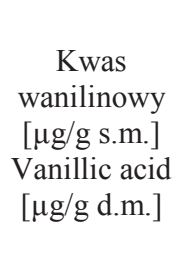 & $\begin{array}{c}\text { Kwas } \\
\text { protokatechowy } \\
{[\mu \mathrm{g} / \mathrm{g} \text { s.m.] }} \\
\text { Protocatechuic } \\
\text { acid }[\mu \mathrm{g} / \mathrm{g} \text { d.m.] }\end{array}$ & $\begin{array}{c}\text { Biodostępność } \\
\text { polifenoli in } \\
\text { vitro } \\
\text { Bioavialiability } \\
\text { in vitro of } \\
\text { polyphenols } \\
{[\%]}\end{array}$ \\
\hline $\begin{array}{l}\text { Pieczywo } 1 \\
\text { Bread } 1\end{array}$ & $14,94^{\mathrm{a}} \pm 1,36$ & $3,67^{\mathrm{a}} \pm 0,19$ & $41,86^{b} \pm 2,63$ & $0,44^{\mathrm{a}} \pm 0,05$ & $30,7^{\mathrm{d}} \pm 1,9$ \\
\hline $\begin{array}{l}\text { Pieczywo } 2 \\
\text { Bread } 2\end{array}$ & $38,60^{c} \pm 4,79$ & $3,75^{\mathrm{a}} \pm 0,56$ & $36,38^{\mathrm{b}} \pm 4,34$ & $3,40^{\mathrm{b}} \pm 0,48$ & $21,0^{b} \pm 1,3$ \\
\hline $\begin{array}{l}\text { Pieczywo } 3 \\
\text { Bread } 3\end{array}$ & $55,66^{\mathrm{d}} \pm 6,94$ & $3,41^{\mathrm{a}} \pm 0,34$ & $43,56^{\mathrm{b}} \pm 5,45$ & $3,79^{\mathrm{b}} \pm 0,29$ & $17,8^{\mathrm{a}} \pm 1,3$ \\
\hline $\begin{array}{l}\text { Pieczywo } 4 \\
\text { Bread } 4\end{array}$ & $46,23^{\mathrm{cd}} \pm 5,77$ & $3,82^{\mathrm{a}} \pm 0,56$ & $42,20^{\mathrm{b}} \pm 7,14$ & $3,62^{\mathrm{b}} \pm 0,51$ & $22,8^{b} \pm 1,4$ \\
\hline $\begin{array}{l}\text { Pieczywo } 5 \\
\text { Bread } 5\end{array}$ & $36,74^{c} \pm 6,68$ & $3,67^{\mathrm{a}} \pm 0,20$ & $39,75^{\mathrm{b}} \pm 3,38$ & $3,79^{\mathrm{b}} \pm 0,57$ & $24,9^{\mathrm{bc}} \pm 2,9$ \\
\hline $\begin{array}{l}\text { Pieczywo } 6 \\
\text { Bread } 6\end{array}$ & $24,15^{b} \pm 4,08$ & $3,57^{\mathrm{a}} \pm 0,16$ & $23,58^{\mathrm{a}} \pm 2,44$ & $2,66^{\mathrm{b}} \pm 0,02$ & $26,7^{\mathrm{c}} \pm 1,5$ \\
\hline $\begin{array}{l}\text { Pieczywo } 7 \\
\text { Bread } 7\end{array}$ & $15,08^{\mathrm{a}} \pm 2,87$ & $3,03^{\mathrm{a}} \pm 0,38$ & $26,37^{\mathrm{a}} \pm 2,21$ & $3,10^{\mathrm{b}} \pm 0,53$ & $21,6^{\mathrm{bc}} \pm 4,3$ \\
\hline
\end{tabular}

Objaśnienia / Explanatory notes:

Charakterystyka próbek zgodnie $\mathrm{z}$ tab. 1. / Profile of samples according to Tab. 1. W tabeli przedstawiono wartości średnie \pm odchylenia standardowe / Table shows mean values \pm standard deviation; $\mathrm{n}=6$; $\mathrm{a}, \mathrm{b}, \mathrm{c}$, d - wartości średnie w kolumnach oznaczone różnymi literami różnią się statystycznie istotnie przy $\mathrm{p} \leq 0,05$ / mean values in columns denoted by different letters differ statistically significantly $\mathrm{p} \leq 0.05$.

\section{Witaminy $B_{1}$ oraz $B_{2}$}

Tiamina $\left(\mathrm{B}_{1}\right)$ i ryboflawina $\left(\mathrm{B}_{2}\right)$ to dwie witaminy $\mathrm{z}$ grupy $\mathrm{B}$, które pełnią istotną funkcję $\mathrm{w}$ różnych procesach metabolicznych $\mathrm{w}$ organizmie człowieka, m.in. w metabolizmie glukozy, neurotransmisji, replikacji genów czy rozwoju tkanek płodowych i biosyntezie kortykosteroidów [5, 23]. Obie witaminy są wrażliwe na wpływ temperatury, światła i innych czynników, którym poddawane są ziarna zbóż. Procesy technologiczne mogą częściowo degradować te biokomponenty w zakresie od $25 \%$ (tiamina) do nawet $50 \%$ (ryboflawina) wyjściowego ich poziomu w surowcu [1, 15, 29]. Z tego powodu wiele produktów zbożowych wytwarzanych przemysłowo wzbogacanych jest $\mathrm{w}$ witaminy $\mathrm{z}$ grupy $\mathrm{B} \mathrm{w}$ celu odzyskania ich pierwotnego poziomu. Ponadto u znaczącej części populacji notuje się niedobory ryboflawiny [23] czy też tiaminy - w tym przypadku wzbogacanie ma na celu zniwelowanie ryzyka zapadalności na syndrom Wernicke-Korsakoffa [26]. 
Zawartości zarówno tiaminy $\left(\mathrm{B}_{1}\right)$, jak i ryboflawiny $\left(\mathrm{B}_{2}\right)$ w pieczywie żytnim (pieczywo kontrolne - P7 odpowiednio: $138 \mu \mathrm{g} / \mathrm{g}$ oraz $28 \mu \mathrm{g} / 100 \mathrm{~g}$ ) były zbliżone do wartości referencyjnych podawanych w publikacjach innych autorów $(145 \mu \mathrm{g} / 100 \mathrm{~g}$ oraz $50 \mu \mathrm{g} / 100 \mathrm{~g}$ ) [15]. Analiza danych przedstawionych na rys. 1. wskazuje, że tendencja wzrostu zawartości witamin dotyczy zwłaszcza próbek pieczywa 2 - 5 wzbogaconych dodatkiem Arthrospira platensis w dawce 50 - $40 \mathrm{~g} / \mathrm{kg}$ surowca do wypieku oraz dodatkowo 5 - $10 \mathrm{~g} / \mathrm{kg}$ Ascophyllum nodosum.

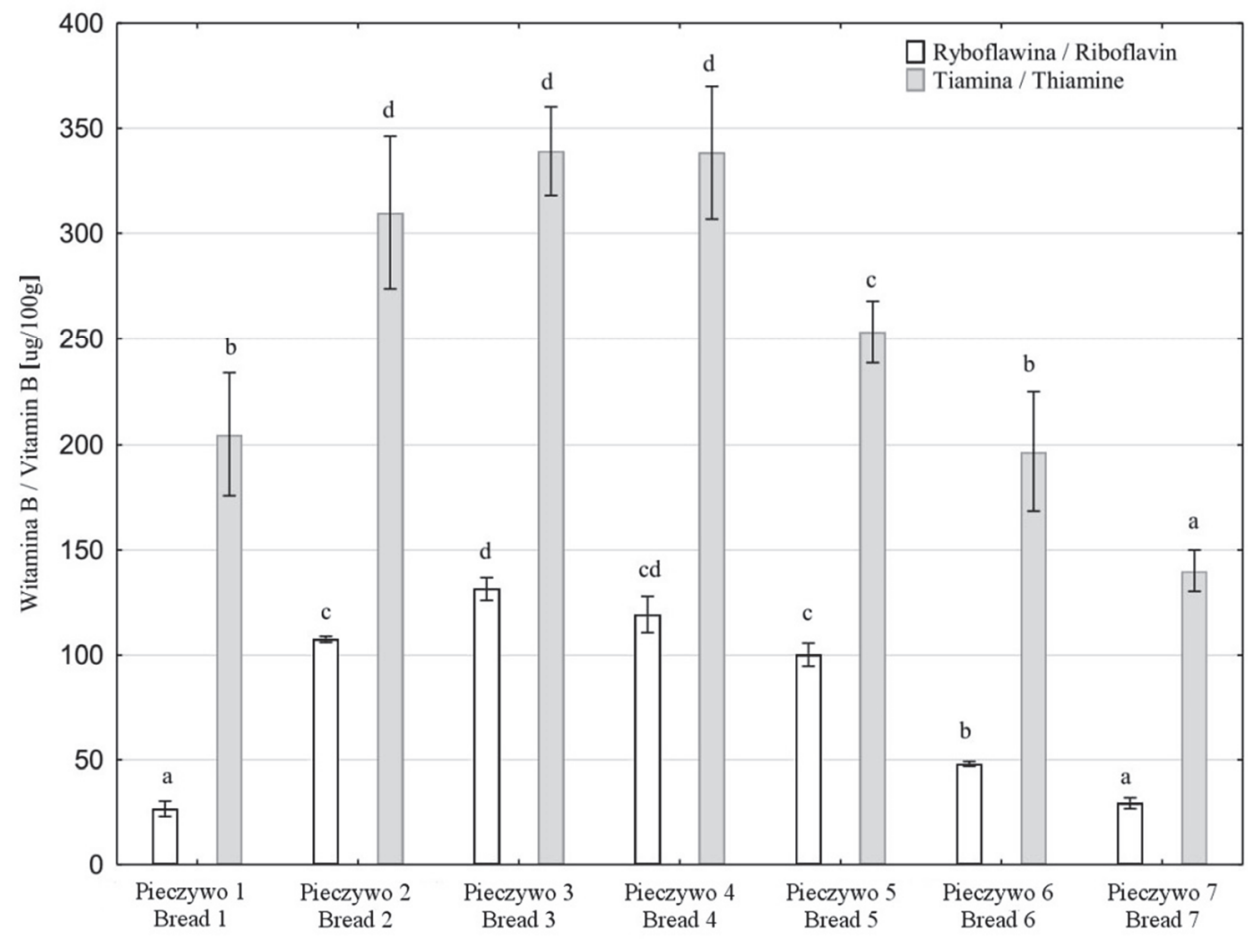

Objaśnienia / Explantatory notes:

Charakterystyka próbek zgodnie $\mathrm{z}$ tab. 1. / Profile of samples according to Table 1. Na rysunku przedstawiono wartości średnie (w postaci słupków) i odchylenia standardowe (w postaci odcinków) / Figure shows mean values (bars) and standard deviations (line segments); a - d - wartości średnie oznaczone różnymi literami różnią się statystycznie istotnie przy $\mathrm{p} \leq 0,05$ / mean values denoted by different letters differ statistically significantly at $\mathrm{p} \leq 0.05$.

Rys. 1. Zawartość tiaminy $\left(\mathrm{B}_{1}\right)$ oraz ryboflawiny $\left(\mathrm{B}_{2}\right)$ w pieczywie wzbogaconym w algi

Fig. 1. Contents of thiamine $\left(B_{1}\right)$ and riboflavin $\left(B_{2}\right)$ in algae-enriched bread

Na podstawie uzyskanych wyników badań stwierdzono, że wprowadzenie na etapie mieszenia ciasta żytniego dodatków algowych w znaczącym stopniu przyczyniło się do wzrostu dostępnej puli witamin z grupy B w pieczywie, zwłaszcza ryboflawiny 
$\left(\mathrm{B}_{2}\right)$. W przypadku najbardziej zasobnych w ryboflawinę próbek pieczywa 3 i 4 oznacza to - przy założeniu dziennej konsumpcji ok. $150 \mathrm{~g}$ chleba - wypełnienie blisko $30 \%$ zalecanej normy spożycia witaminy $(1,1 \div 1,3 \mathrm{mg})$ [27] przy zachowaniu porównywalnej - wobec próby kontrolnej - dostępności in vitro tego składnika na poziomie $60 \%$. Szacowana techniką in vitro biodostępność witaminy $\mathrm{B}_{2} \mathrm{w}$ pieczywie żytnim (45 $\div 62 \%$ ) jest zbieżna z wynikami Kurka i wsp. [10] w przypadku pieczywa z mąki pszennej, w którym biodostępność kształtowała się na poziomie $47 \div 50 \%$. Relatywnie wysoka biodostępność in vitro pieczywa 6 może wynikać z maksymalnego dodatku makroalgi A. nodosum (15 g/kg mąki) i korzystnego wpływu obecnych w jej biomasie hydrokoloidów na wchłanianie składników bioaktywnych [4].

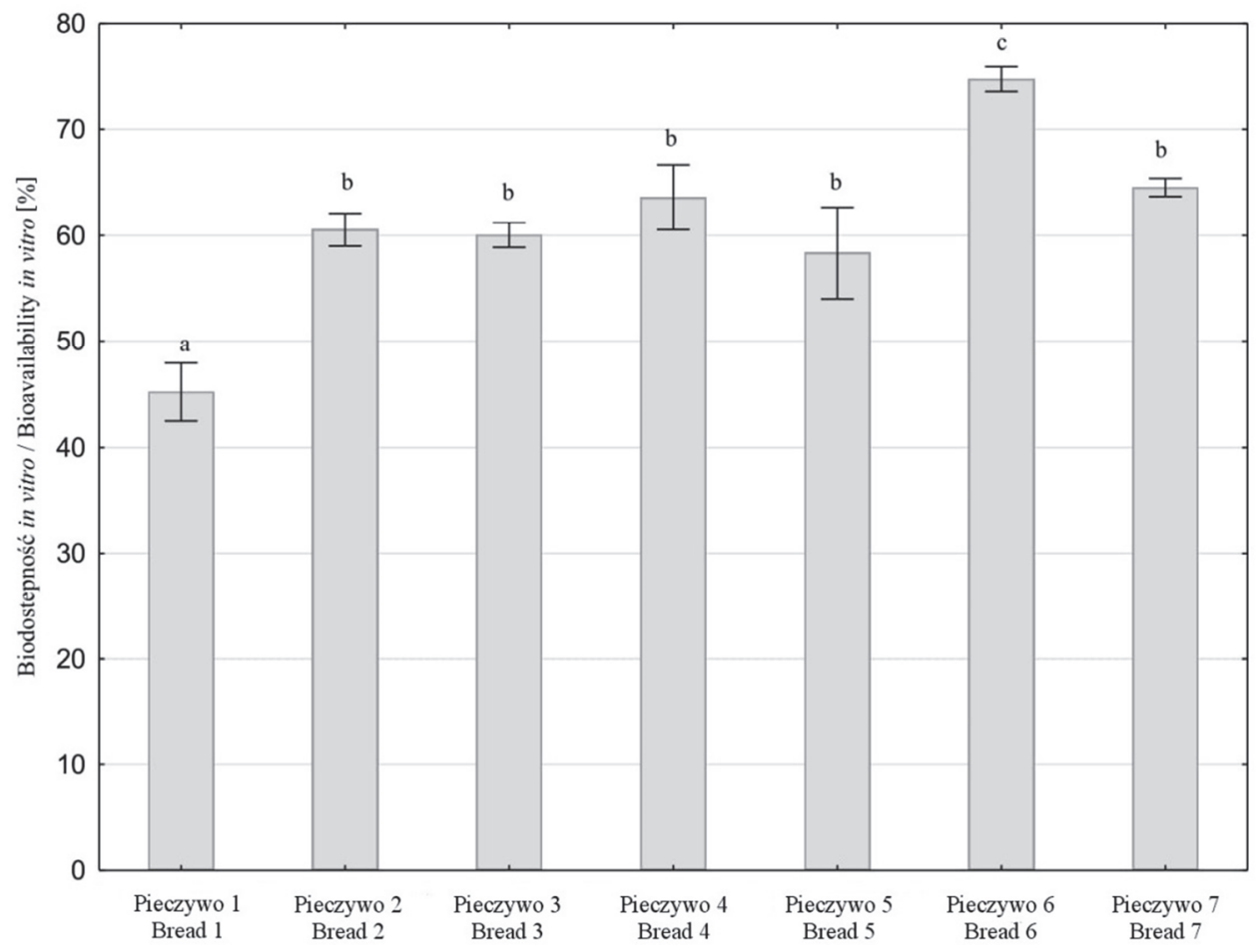

Objaśnienia jak pod rys. 1. / Explanatory notes as in Fig. 1.

Rys. 2. Biodostępność witaminy $\mathrm{B}_{2}$ (ryboflawiny) w pieczywie wzbogaconym w algi szacowana metodą in vitro

Fig. 2. In vitro bioavailability of vitamin $\mathrm{B}_{2}$ (riboflavin) in algae-enriched breadstuffs

Jedną $\mathrm{z}$ opcji wzbogacania pieczywa w witaminę $\mathrm{B}_{2}$ jest wprowadzanie oczyszczonej ryboflawiny do surowca lub półproduktu, ale jeszcze korzystniejszym wariantem, z punktu widzenia biodostępności, jest wzbogacanie ciasta składnikami pocho- 
dzenia naturalnego. Podejmowane są również próby selekcji szczepów mikroorganizmów (np. Lactobacillus fermentum) stosowanych w procesie fermentacji do zwiększenia zawartości ryboflawiny $\mathrm{w}$ pieczywie czy jogurtach [22]. Z porównania uzyskanych w ten sposób efektów wzbogacenia pieczywa w ryboflawinę (14 $\mu \mathrm{g}$ witaminy $\mathrm{B}_{2} / 100 \mathrm{~g}$ produktu) wynika, że zaprojektowane $\mathrm{w}$ ramach podjętych badań pieczywo charakteryzowało się zdecydowanie wyższymi współczynnikami przy akceptowanej, relatywnie wysokiej szacowanej in vitro biodostępności tego składnika (45 $62 \%)$ - rys. 2.

W przypadku tiaminy nie obserwowano tak dużych wzrostów zawartości tej witaminy wraz z dodatkiem składnika algowego, tym niemniej tendencje odnotowane w przypadku ryboflawiny potwierdzono $\mathrm{w}$ analizach tiaminy. Najwyższy poziom tiaminy oznaczono w próbkach pieczywa 3 oraz 4 (odpowiednio: 336 i $337 \mu \mathrm{g} / 100 \mathrm{~g}$ ) (rys. 1). Te partie przygotowano poprzez dodatek do wyjściowego surowca $50 \mathrm{~g} / \mathrm{kg} A$. platensis (pieczywo 4) uzupełniony dodatkowo o $10 \mathrm{~g} / \mathrm{kg}$ A. nodosum $\mathrm{w}$ przypadku próbki nr 3, co stanowi wzrost o $140 \div 145 \%$ wobec próby kontrolnej bez dodatku alg (P7: $139 \mu \mathrm{g} / 100 \mathrm{~g}$ ). Oznacza to również, że efekt ubytku zawartości tiaminy wskutek obróbki technologicznej i hydrotermicznej ziarna $\mathrm{w}$ trakcie przygotowania surowca i wypieku pieczywa (szacowany na $25 \div 50 \%$ ) [26] został zniwelowany poprzez dodatek bioaktywnego składnika algowego.

\section{Wnioski}

1. Funkcjonalne pieczywo zaprojektowane w ramach niniejszych badań charakteryzowała podwyższona zawartość ryboflawiny oraz tiaminy, zwłaszcza w próbkach wzbogaconych w najwyższe dawki biomasy alg, czyli $50 \mathrm{~g}$ Arthrospira platensis i $10 \mathrm{~g}$ Ascophyllum nodosum na kilogram mąki.

2. Stwierdzono statystycznie istotny, pozytywny wpływ dodatku algowego na zawartość wybranych kwasów fenolowych, zwłaszcza kwasu galusowego oraz wanilinowego.

3. Pomimo 2-, 3-krotnego wzrostu zawartości ryboflawiny odnotowanego w próbkach pieczywa wzbogaconych $w$ algi biodostępność witaminy $\mathrm{B}_{2}$ szacowana techniką in vitro pozostała na wysokim, porównywalnym z próbą kontrolną poziomie (ok. $60 \%$ ).

4. Wprowadzone zmiany w podstawowej recepturze pieczywa pozwoliły uzyskać nowy produkt piekarniczy o cechach żywności funkcjonalnej.

\section{Podziękowania}

Autorzy pracy sktadaja podziękowania właścicielom piekarni „Prawdziwy chleb” Pani Agnieszce Gajdzie-Sokołowskiej oraz Panu Hubertowi Sokołowskiemu za przygotowanie eksperymentalnych partii pieczywa. 
Projekt finansowany w ramach dotacji Ministerstwa Nauki i Szkolnictwa Wyższego na działalność statutowa.

\section{Literatura}

[1] Giménez P.J., Fernández-López J.A., Angosto J.M., Obón J.M.: Comparative thermal degradation patterns of natural yellow colorants used in foods. Plant. Foods Hum. Nutr., 2015, 70 (4), 380-387.

[2] Gouveia L., Marques A.E., Sousa J.M., Moura P., Bandarra N.M.: Microalgae - source of natural bioactive molecules as functional ingredients. Food Sc. Technol. Bull. Funct. Foods., 2010, 7 (2), 2137.

[3] Herrero M., Sánchez-Camargo A.P., Cifuentes A., Ibáñez E.: Plants, seaweeds, microalgae and food by-products as natural sources of functional ingredients obtained using pressurized liquid extraction and supercritical fluid extraction. TrAC Trends Anal. Chem., 2015, 71, 26-38.

[4] Houghton D., Wilcox M.D., Chater P.I., Brownlee I.A., Seal C.J., Pearson J.P.: Food hydrocolloids biological activity of alginate and its effect on pancreatic lipase inhibition as a potential treatment for obesity. Food Hydrocoll., 2015, 49, 18-24.

[5] Importance B.: Vitamin B 1 . Disease-a-month., 2003, 49 (11), 646-652.

[6] De Jesus Raposo M.F., de Morais R.M.S.C., de Morais A.M.M.B.: Health applications of bioactive compounds from marine microalgae. Life Sci., 2013, 93 (15), 479-486.

[7] Jha D., Jain V., Sharma B., Kant A., Garlapati V.K.: Microalgae-based pharmaceuticals and nutraceuticals: An emerging field with immense market potential. Chem. Bio. Eng. Rev., 2017, 4, 257-272.

[8] Kadam S.U., Prabhasankar P.: Marine foods as functional ingredients in bakery and pasta products. Food Res. Int., 2010, 43, 1975-1980.

[9] Katina K., Arendt E., Liukkonen K.H., Autio K., Flander L., Poutanen K.: Potential of sourdough for healthier cereal products. Trends Food Sci. Technol., 2005, 16 (1-3), 104-112.

[10] Kurek M.A., Wyrwisz J., Karp S., Wierzbicka A.: Particle size of dietary fiber preparation affects the bioaccessibility of selected vitamin B in fortified wheat bread. J. Cereal Sci., 2017, 77, 166-171.

[11] Liu L., Pohnert G., Wei D.: Extracellular metabolites from industrial microalgae and their biotechnological potential. Mar. Drugs., 2016, 14 (10), 191.

[12] Machu L., Misurcova L., Ambrozova J.V., Orsavova J., Mlcek J., Sochor J., Jurikova T.: Phenolic content and antioxidant capacity in algal food products. Molecules, 2015, 20 (1), 1118-1133.

[13] Manirafasha E., Ndikubwimana T., Zeng X., Lu Y., Jing K.: Phycobiliprotein: Potential microalgae derived pharmaceutical and biological reagent. Biochem. Eng. J., 2016, 109, 282-296.

[14] Matos Â.P.: The impact of microalgae in food science and technology. J. Am. Oil Chem. Soc., 94 (11), 1333-1350.

[15] Mihhalevski A., Nisamedtinov I., Hälvin K., Ošeka A., Paalme T.: Stability of B-complex vitamins and dietary fiber during rye sourdough bread production. J. Cereal Sci., 2013, 57 (1), 30-38.

[16] Ores J.D.C., Amarante M.C.A., Kalil S.J.: Co-production of carbonic anhydrase and phycobiliproteins by Spirulina sp. and Synechococcus nidulans. Bioresour Technol., 2016, 219, 219227.

[17] Ovando C.A., Carvalho J.C., Melo G.V., Jacques P., Soccol V.T., Soccol C.R.: Functional properties and health benefits of bioactive peptides derived from Spirulina: A review. Food Rev. Int., 2016, 34, 34-51.

[18] Packer M.A., Harris G.C., Adams S.L.: Food and feed applications of algae. In: Algae Biotechnology: Products and Processes. Eds. F. Bux, Y. Chisti. Springer Nature, Basel 2016, pp. 217-247. 
[19] Batista A.P., Niccolai A., Fradinho P., Fragoso S., Bursic I., Rodolfi L., Biondi N., Tredici M.R., Sousa I., Raymundo A.: Microalgae biomass as an alternative ingredient in cookies: Sensory, physical and chemical properties, antioxidant activity and in vitro digestibility. Algal Res., 2017, 26, 161-171.

[20] Pihlava J.M., Nordlund E., Heiniö R.L., Hietaniemi V., Lehtinen P., Poutanen K.: Phenolic compounds in wholegrain rye and its fractions. J. Food Compos. Anal., 2015, 38, 89-97.

[21] Quirós A.R.: Determination of phenolic compounds in macroalgae for human consumption. Food Chem., 2010, 121 (2), 634-638.

[22] Russo P., Capozzi V., Arena M.P., Spadaccino G., Dueñas M.T., López P., Fiocco D., Spano G.: Riboflavin-overproducing strains of Lactobacillus fermentum for riboflavin-enriched bread. Appl. Microbiol. Biotechnol., 2014, 98 (8), 3691-3700.

[23] Schwechheimer S.K., Park E.Y., Revuelta J.L., Becker J., Wittmann C.: Biotechnology of riboflavin. Appl. Microbiol. Biotechnol., 2016, 100 (5), 2107-2119.

[24] Starzyńska-Janiszewska A., Duliński R., Stodolak B., Mickowska B., Wikiera A.: Prolonged tempetype fermentation in order to improve bioactive potential and nutritional parameters of quinoa seeds. J. Cereal Sci., 2016, 71, 116-121.

[25] Starzyńska-Janiszewska A., Stodolak B., Duliński R., Bączkowicz M., Mickowska B., Wikiera A., Byczyński Ł.: Effect of solid-state fermentation tempe type on antioxidant and nutritional parameters of buckwheat groats as compared with hydrothermal processing. J. Food Process. Preserv., 2016, 40 (2), 298-305.

[26] Tiong S.A., Chandra-Hioe M.V., Arcot J.: Thiamin fortification of bread-making flour: Retention in bread and levels in Australian commercial fortified bread varieties. J. Food Compos. Anal., 2015, 38, 27-31.

[27] Turck D., Bresson J., Burlingame B., Dean T., Fairweather-Tait S., Heinonen M., Hirsch-Ernst K.I., Mangelsdorf I., McArdle H.J., Naska A., Nowicka G., Pentieva K., Sanz Y., Siani A., Sjödin A., Stern M., Tomé D., Loveren H.V., Vinceti M., Willatts P., Lamberg-Allardt C., Przyrembel H., Tetens I., Dumas C., Fabiani L., Forss A.C., Ioannidou S., Neuhäuser-Berthold M.: Dietary reference values for riboflavin. EFSA J., 2017, 15 (8).

[28] Vaz B.S., Moreira J.B., Morais M.G., Costa J.A.V.: Microalgae as a new source of bioactive compounds in food supplements. Curr. Opin. Food Sci., 2016, 7, 73-77.

[29] Wolak N., Zawrotniak M., Gogól M., Kozik A., Rąpała-Kozik M.: Vitamins $B_{1}, B_{2}, B_{3}$ and $B_{9}$ : Occurrence, biosynthesis pathways and functions in human nutrition. Mini-Reviews Med. Chem., 2017, 17 (12), 1075-1111.

[30] Wu Q., Liu L., Miron A., Klímová B., Wan D., Kuča K.: The antioxidant, immunomodulatory, and anti-inflammatory activities of Spirulina: An overview. Arch. Toxicol., 2016, 90 (8), 1817-1840.

[31] Zyla K., Ledoux D.R., Veum T.L.: Complete enzymic dephosphorylation of corn-soybean meal feed under simulated intestinal conditions of the turkey. J. Agric. Food Chem., 1995, 43 (2), 288-294.

[32] Innowacyjne ciastka i chlebki Dulcesol Innova należące do hiszpańskiej firmy Dulcesol Group i zawierające w składzie 0,4 \% alg Chlorella vulgaris [on line]. Dostęp w Internecie [08.11.2018]: http://en.dulcesol.com/ver/6221/dulcesol-innova.html 


\title{
DETERMINING CONTENTS OF SELECTED PHENOLIC ACIDS AND VITAMINS OF B GROUP IN RYE BREADSTUFFS ENRICHED WITH ALGAE AND ESTIMATING THEIR IN VITRO BIOAVAILABILITY
}

\author{
S u m m a ry
}

In recent years, we have been observing a growing interest in supplementing food with extracts or other components derived from biomass of microalgae. The composition and properties of microalgae and macroalgae (seaweed) make them not only a supplementing component to restore deficiency of the selected, biologically active ingredients in the diet but, also, essential factors to impact functional and pro-health features of the product.

In the research study, it was attempted to design functional breadstuffs containing extracts from $\mathrm{Ar}$ throspira platensis and Ascophyllum nodosum algae. Some selected bioactive components in the algae were analysed and their bioavailability was estimated using an in vitro technique. Based on the results of the HPLC determination and, next, of the simulation of digestion in the human gastrointestinal tract, it was showed that enriching rye breadstuffs with algae caused the content of vitamin $\mathrm{B}_{2}$ to increase 2 to 3 times; in the case of one of the bread variants, this increase provided nearly $30 \%$ of the recommended daily intake of riboflavin and it caused the content of thiamine to rise 50 to $145 \%$ compared to the content of that vitamin in the bakery products without algal additives at a comparable level of the in vitro bioavailability of the control sample $(60 \%)$. In the breadstuffs designed, a significant increase, ranging from 17 to $30 \%$, was also reported in the content of the selected phenolic acids, mostly of the gallate and vanillinate, at a different level of the in vitro bioavailability of the polyphenols in total. The results of the analyses presented as well as the positive (unpublished) data obtained by using sensory tests bring promising prospects for the introducing of functional breadstuffs with algae additives into the bakery products market.

Key words: microalgae, Arthrospira platensis, phenolic acids, riboflavin, thiamine, bioavailability 